\title{
Sensory Lexicons and Formation Pathways of Off-Aromas in Dairy Ingredients: A Review
}

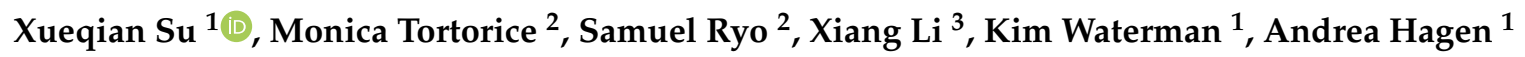 \\ and Yun Yin ${ }^{1, *}$ \\ 1 Department of Food Science and Technology, Virginia Polytechnic Institute and State University, \\ 1230 Washington Street SW, Blacksburg, VA 24061, USA; xueqians@vt.edu (X.S.); kwater@vt.edu (K.W.); \\ andreah2@vt.edu (A.H.) \\ 2 Abbott Laboratories, 3300 Stelzer Rd, Columbus, OH 43219, USA; monica.tortorice@abbott.com (M.T.); \\ samuelryo@gmail.com (S.R.) \\ 3 Abbott Nutritional Research and Development Center, 20 Biopolis Way, Singapore 138668, Singapore; \\ xiang.li@abbott.com \\ * Correspondence: yunyin2@vt.edu; Tel.: +1-540-231-2029
}

Academic Editor: Ryszard Amarowicz

Received: 27 November 2019; Accepted: 23 January 2020; Published: 28 January 2020

\begin{abstract}
Consumers are becoming increasingly aware of the health benefits of dairy ingredients. However, products fortified with dairy proteins are experiencing considerable aroma challenges. Practices to improve the flavor quality of dairy proteins require a comprehensive understanding of the nature and origins of off-aroma. Unfortunately, existing information from the literature is fragmentary. This review presents sensory lexicons and chemical structures of off-aromas from major dairy ingredients, and it explores their possible precursors and formation mechanisms. It was found that similar chemical structures often contributed to similar off-aroma descriptors. Lipid degradation and Maillard reaction are two primary pathways that commonly cause aroma dissatisfaction. Traditional and novel flavor chemistry tools are usually adopted for off-aroma measurements in dairy ingredients. Strategies for improving aroma quality in dairy derived products include carefully selecting starting materials for formulations, and actively monitoring and optimizing processing and storage conditions.
\end{abstract}

Keywords: off-aroma; lexicons; chemical structure; dairy; sensory; formation pathway

\section{Introduction}

Flavor is one of the most important characteristics that directly determines the acceptance of foods. As the first sensory impression, a good flavor profile is critically important when consumers are first exposed to a product. The ultimate goal of any food development is to achieve a desirable flavor quality that consumers will enjoy. A good flavor profile is generally defined by an immediate sensation of an identifiable aroma, a rapid development of a balanced flavor, compatible mouthfeel and texture, and most importantly, minimal off-flavor presence [1].

Essentially, food flavor defects include taints and off-flavors. Taints are usually considered to be unpleasant odors and flavors imparted to food through external sources, such as the environment, packaging aids, and air. Off-flavors refer to undesirable odors and flavors imparted to food through internal deterioration. Examples include oxidation and microbial deterioration caused by improper handling and storage [2]. This review will primarily focus on the off-flavors that arise through the presence of aroma substances, that is, the off-aromas. Off-aromas usually occur when the concentration of a volatile compound in the food matrix is so high that it exceeds the general tolerance of human subjects. This off-note concentration at which consumers begin to reject the product is called the rejection threshold. Generally speaking, the rejection threshold more sensitively reflects the consumers' 
preference towards one product when compared to the detection threshold and the recognition threshold [3,4]. Off-aromas create severe issues and affect food product quality along the supply chain. Off-aroma presence has also been reported to be the most common reason for consumer rejection of products, and it accounts for the largest percentage of complaints in the food industry [5]. In order to avoid financial loss to manufacturers and improve consumer confidence in brand images, minimizing unpleasant flavor experiences in food products becomes a primary mission in the modern food industry.

Many ingredients fall into the dairy category, including both dried and fluid dairy proteins. Whey and milk proteins, caseins, and serum proteins are well-known dried dairy ingredients. Fluid ingredients, such as whole milk, low-fat milk, and non-fat milk, are also included in the dairy category [6]. Although there has been increasing consumer interest in plant-based proteins due partially to changing consumer behavior and concerns about health and animal welfare, the dairy protein industry is still growing and generating great economic value $[7,8]$. According to the Global Dairy Protein Market 2019 Industry Research Report, the global dairy protein market was worth $\$ 15.04$ billion in 2017 and is estimated to be valued at $\$ 19.88$ billion by 2023 . This represents a $5.8 \%$ increase in the annual compound growth rate. The dairy protein market can be segmented into various sectors based on ingredients and applications, and the food and beverage branch is constantly expanding and innovating [9]. Also, dairy ingredients are being utilized to develop a large portion of high-protein drinks. While the nutritional value is highly appreciated, products fortified with dairy proteins face significant challenges in flavor satisfaction. In fact, the addition of protein to a food product may impart undesirable off-aromas or change its original aroma profile due to interaction, binding or the release of volatiles [10]. Flavoring high-protein foods has been particularly challenging to food industry because of the various aroma origins, from both raw materials and from processing and storage. Aroma imbalance and fading are commonly observed issues.

Taking proactive approaches throughout the product development stage will encourage off-aroma prevention. Senior flavor scientists have advised food manufacturers to partner with flavor suppliers to develop solutions early in the process. More importantly, off-aroma knowledge should be disseminated to a wider group of audiences, including ingredient suppliers, product developers, processing engineers, sensory scientists, marketing professionals, and consumers, in order to overcome the aroma dissatisfaction associated with dairy ingredients. Sensory lexicons play an important role in knowledge dissemination among diverse audiences. Building bridges between off-aroma lexicons, chemical natures, and formation mechanisms will not only assist effective communication between different parties but will also aid the targeted resolution of aroma imperfection and improve the sensory quality for final products. Furthermore, understanding the precursors and formation mechanisms will provide opportunities for accurately locating off-aroma occurrence throughout the supply chain and enable immediate problem-solving actions. Several review articles provide insightful discussion on aroma and sensory challenges in dairy-related products $[1,6,11,12]$. However, to our best knowledge, a comprehensive picture of chemistry and sensory descriptors for off-aroma compounds is not yet available. This review will fill in the abovementioned knowledge gap.

\section{Investigating Off-Aroma Sensory Descriptions and Their Chemical Natures in Dairy Proteins}

The primary quest in flavor research is to characterize chemical compounds that provide specific sensory attributes to the aroma of foods [10]. Relating the chemical and sensory responses of off-aroma in foods is one of our major focuses. Sensory perception is heavily influenced by cultural and emotional experiences. The actual sensation process is largely determined by the physicochemical nature of volatile compounds responsible for off-notes, their concentration in food matrices, and the sensitivity of human subjects [13]. Besides traditional sensory panels, off-note lexicons can also be generated from an olfactometer equipped to a gas chromatograph (GCO). The odors of effluent volatile compounds from the separation column are detected and evaluated by the human nose, thereby establishing an association between the lexicons and the chemical structures [14,15]. The positive identification of the chemical structures of unknown volatiles occurs by matching the mass spectrum, 
odor attributes, and retention indices against authentic aroma standards. GCO has been used as an effective tool for unveiling the chemical structures and odors of off-note volatile compounds in dairy ingredients. For example, "cheesy", "potato", "popcorn", and "cabbage" were perceived as major off-aroma descriptors by use of an olfactometer. By comparing these odor attributes and mass spectrum with aroma standards, these descriptors were respectively confirmed to be butanoic acid, methional, 2-acetyl-1-pyrroline, and dimethyl trisulfide [16].

The chemical natures and sensory lexicons of selected off-note volatile compounds are listed in Table 1. They are either preexisting in raw ingredients or formed during product manufacturing or storage. Some lexicons, like "rancid", "green", "garlic", and "vinegar", are commonly found in many dairy ingredients. This is not surprising since the compositional profiles of dairy ingredients are relatively similar to their constituent components of protein, fat, and lactose. The odor attributes of some compounds are described using similar lexicons, especially those that belong to the same homologous series. For example, the odor attributes of $(E, E)$-2,4-decadienal and $(E, E)$-2,4-nonadienal were both recorded as "frying oil", and the acids generally exhibit a "sweaty" and "rancid" note (Figure 1). It might be helpful for sensory scientists and product developers to keep in mind that structurally similar compounds are likely to exhibit similar or identical sensory characteristics. However, exceptions do occur: Hexanal (C6) and octanal (C8) display distinctly different odor qualities because their excitation mechanisms on olfactory receptors are different $[17,18]$. Special attention should be paid to sulfur-containing volatile compounds having "cabbage" and/or "sulfurous" odors, as they can be significant off-aroma contributors at extremely low odor thresholds. It is also worth mentioning that the discussion of off-note compounds should be based on the particular food matrix or ingredient because a compound considered as an off-aroma in one food might have a desirable note in another [19]. "Popcorn" and "cereal" odors owing to the presence of heterocyclic volatiles, including 2-acetyl-1-pyrroline, are considered to be off-aromas or foreign smells in dairy ingredients, because product developers generally prefer starting materials with a "plain" or "clean" flavor profile. However, 2-acetyl-1-pyrroline is a characteristic compound found in aromatic rice, bakery goods, and seafood. Although the complex chemistry makes off-note solutions in dairy ingredients a challenging task, demonstration of the association between lexicons and chemical structures will enhance our understanding of the nature of off-aromas and assist problem-solving strategies.

Table 1. Sensory lexicons and chemical natures of selected off-aroma compounds in major dairy ingredients.

\begin{tabular}{cccc}
\hline Ingredients & $\begin{array}{c}\text { Major Off-Aroma } \\
\text { Lexicons }\end{array}$ & Chemical Compounds & References \\
\hline & Cheesy/Rancid & Butanoic acid & {$[16]$} \\
Popcorn & 2-Acetyl-1-pyrroline & {$[16]$} \\
& Maple/Spicy & Sotolon & {$[16]$} \\
& Cucumber & $(E, Z)-2,6-$-Nonadienal & {$[16]$} \\
\cline { 2 - 4 } & Cucumber/Old books & $(E)-2-$ Nonenal & {$[16]$} \\
Whey protein & Cabbage & Dimethyl trisulfide & {$[16,20]$} \\
concentrate and isolate & Garlic & Dimethyl trisulfide & {$[21]$} \\
& Vinegar & Acetic acid & {$[20]$} \\
& Mushroom & $1-$ Octen-3-one & {$[21]$} \\
& Fatty/Smoky & 2-Methoxy phenol & {$[21]$} \\
& Fatty & Decanal & {$[21]$} \\
& Fatty/Stale & Decanoic acid & {$[21]$} \\
Whey Protein & Cilantro/Waxy & $\gamma$-Nonalactone & {$[21]$} \\
\hline Hydrolysates & Sulfur & Dimethyl sulfide & {$[22]$} \\
& Potato & Methional & {$[22]$} \\
& Burnt/Smoky & Guaiacol & {$[22]$} \\
\hline
\end{tabular}


Table 1. Cont.

\begin{tabular}{|c|c|c|c|}
\hline Ingredients & $\begin{array}{l}\text { Major Off-Aroma } \\
\text { Lexicons }\end{array}$ & Chemical Compounds & References \\
\hline \multirow{4}{*}{ Sweet whey powder } & Vinegar-like & Acetic acid & [23] \\
\hline & Grassy & Heptanal & [23] \\
\hline & Cooked potato & 2,5-Dimethylpyrazine & [23] \\
\hline & Fried & 2-Propionyl-1-pyrroline & [23] \\
\hline \multirow{5}{*}{ Liquid cheddar whey } & Green & Hexanal & [24] \\
\hline & Popcorn & 2-Acetyl-1-pyrroline & [24] \\
\hline & Potato & Methional & [24] \\
\hline & Frying oil & $(E, E)-2,4$-Decadienal & {$[24]$} \\
\hline & Frying oil & (E,E)-2,4-Nonadienal & [24] \\
\hline \multirow{8}{*}{$\begin{array}{l}\text { Serum protein } \\
\text { concentrate }\end{array}$} & Green/Earthy & Hexanal & [21] \\
\hline & Potato & Methional & [21] \\
\hline & Mushroom & 1-Octen-3-one & [21] \\
\hline & Fatty/Smoky & 2-Methoxy phenol & [21] \\
\hline & Cucumbers & (E)-2-Nonenal & [21] \\
\hline & Fatty & Decanal & {$[21]$} \\
\hline & Fatty/Stale & Decanoic acid & [21] \\
\hline & Cilantro/Waxy & $\gamma$-Nonalactone & [21] \\
\hline \multirow{4}{*}{ Milk protein concentrate } & Potato & Methional & [25] \\
\hline & Popcorn & 2-Acetyl-1-pyrroline & [25] \\
\hline & Carpet/Clay & Benzothiazole & [25] \\
\hline & Vinegar-like & Acetic acid & [25] \\
\hline \multirow{5}{*}{ Milk protein isolate } & Burning plastic & 2-Methyl-1-propanol & [25] \\
\hline & Popcorn & 2-Acetyl-1-pyrroline & [25] \\
\hline & Cabbage/Garlic & Dimethyl trisulfide & [25] \\
\hline & Carpet/Clay & Benzothiazole & [25] \\
\hline & Garbage & Propanoic acid & {$[25]$} \\
\hline \multirow{5}{*}{ Nonfat dry milk } & Burnt sugar & Furaneol & [26] \\
\hline & Rancid & Butanoic acid & {$[26]$} \\
\hline & Grape & $o$-Aminoacetophenone & [26] \\
\hline & Metallic & $(E)-4,5$-Epoxy- $(E)$-2-decenal & [26] \\
\hline & Sweaty & Pentanoic acid & {$[26]$} \\
\hline \multirow{9}{*}{ Whole milk powder } & Cheesy/Rancid & Butanoic acid & [27] \\
\hline & Popcorn & 2-Acetyl-1-pyrroline & [27] \\
\hline & Maple/Spicy & Sotolon & {$[27]$} \\
\hline & Mushroom & 1-Octen-3-one & [27] \\
\hline & Potato & Methional & [27] \\
\hline & Sweaty & Hexanoic acid & [27] \\
\hline & Sweaty & Octanoic acid & [27] \\
\hline & Grape & $o$-Aminoacetophenone & [27] \\
\hline & Fecal/Mothball & 3-Methyl indole & [27] \\
\hline \multirow{8}{*}{ UHT milk } & Cooked/Malty & 3-Methylbutanal & [28] \\
\hline & Barny/Brothy & Furfural & [28] \\
\hline & Cooked & 2-Heptanone & [28] \\
\hline & Earthy/Fatty & Heptanal & [28] \\
\hline & Cooked/Nutty & Benzaldehyde & [28] \\
\hline & Garlic/Cabbage & Dimethyl trisulfide & [28] \\
\hline & Earthy/Barny & $p$-Cresol & [28] \\
\hline & Grass & Octanal & {$[28,29]$} \\
\hline
\end{tabular}




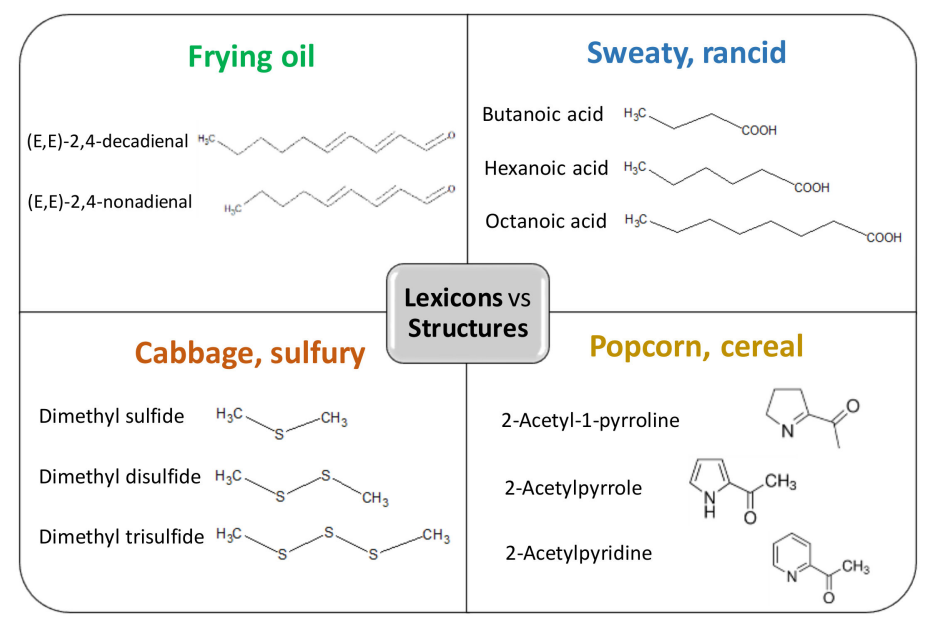

Figure 1. Chemical structures of off-aroma compounds grouped by sensory lexicons.

\section{Understanding the Mechanisms Involved in Primary Formation Pathways of Off-Aromas in Dairy Proteins}

The off-aromas in dairy products primarily originate from the degradation of major milk constituents, including lipids, protein, carbohydrates, minerals, and vitamins. Elucidating the formation mechanisms of aroma defects from such a complex matrix involving many interactions is challenging. Milk, the starting material for almost all dairy ingredients, has a composition of $87 \%$ water, $5 \%$ lactose, $4 \%$ fat, 3\% protein, and 1\% ash. Many flavor researchers agree that the primary sources of off-aroma formation in dairy products are from lipid and protein degradation $[11,25,27,30]$.

\subsection{Lipid Degradation}

Lipid degradation in dairy products is a major cause of deterioration not only due to its undesirable implications for human health but also because it causes decreased overall quality and consumer acceptance [31]. Lipids, present in trace amounts in dairy ingredients, can become significant precursors for off-aromas. The degree of lipid degradation is influenced by water activity, temperature, oxygen, and light [32]. The formation of off-aromas from lipids usually occurs through two routes: Autoxidation and lipolysis $[31,33,34]$. The formation mechanisms, precursors, and odor thresholds of selected volatile compounds generated from lipid degradation (autoxidation and lipolysis) are compiled in Table 2.

\subsubsection{Flavor Significance and Formation Mechanisms of Autoxidation}

Autoxidation is the oxidation of unsaturated lipids. Its reaction with molecular $\mathrm{O}_{2}$ results in the formation of hydroperoxides, which then break down to off-aroma compounds [35]. The widely accepted pathway consists of three stages: Initiation, propagation, and termination [36]. Initiation occurs in the presence of initiators, such as heat, light, and metal. The unsaturated lipid molecules lose a hydrogen atom and produce a carbon-centered alkyl radical. The alkyl radical reacts rapidly with oxygen to form the peroxy radical, which then attacks a new lipid molecule to form hydroperoxide and propagates the chain reaction [37]. This self-propagating and self-accelerating process is repeated until no hydrogen source is available or the chain is interrupted. Hydroperoxides are produced as the primary oxidation products during propagation, and they are odorless and very unstable. The decomposition of hydroperoxides is believed to involve homolytic cleavage between oxygen and oxygen bonds. The resultant alkoxy radical undergoes $\beta$-scission on the carbon-carbon bond and forms oxo-compounds and alkyl radical. After the electron rearrangement, a wide range of secondary lipid oxidation products, including aldehydes, ketones, acids, alcohols, and furans, are produced [36,38] (Table 2). Many of these products have been reported as contributing to off-aromas in dairy products due to their low odor detection thresholds. 
Aldehydes are the most significant breakdown volatiles from alkoxy radicals. In general, their odor thresholds are relatively low (Table 2), making them potent compounds to the overall aroma profile. Often described as "green", "metallic", and "fatty", they are responsible for the undesirable flavors in lipid-containing foods, including dairy products. The final structures of lipid-derived aldehydes depend on the fatty acid precursors, the formed hydroperoxide, and the stability of decomposition products [37]. Multiple generation pathways could be involved in the formation of a particular aldehyde. For instance, the autoxidation of linoleic acid generates 9- and 13-hydroperoxides. Cleavage of 13-hydroperoxide will lead to hexanal, and the breakdown of 9-hydroperoxide will lead to 2,4-decadienal [24,39]. However, the subsequent retro-aldol reaction of 2,4-decadienal will also produce hexanal [37]. Alcohols are formed via cleavage of lipid hydroperoxides during autoxidation of fatty acids [37,38,40]. Although aliphatic alcohols usually have a negligible influence on the overall off-aromas, alcohols like 1-octen-3-ol and 1-penten-3-ol were reported to be important off-aromas in dairy products $[25,41]$. One of the ketones that contributes significantly to off-aromas in whey and milk proteins is 1-octen-3-one [20,27], which has a "mushroom" note. Aliphatic ketones are generally formed by lipid autoxidation [37]. However, the formation mechanism for some ketones, like (Z)-1,5-octadien-3-one and (E,E)-3,5-octadien-2-one, are seldom reported [42]. Furans are well-known autoxidation products from linoleic acid [13,37]. Obviously, linoleic acid is an important precursor for off-note generation (Table 2). A similar perspective was reported by Jeleń (2006) [13] and Kochhar (1996) [43]. Due to the large abundance in foods and high susceptibility to oxidation, linoleic acid and its glycerides are among the most important precursors for aldehyde compounds.

\subsubsection{Flavor Impact and Formation Mechanisms of Lipolysis}

Lipolysis is the hydrolysis of triglycerides, the major lipid component of milk, and it is catalyzed by lipases [33]. The lipases that cause problems in milk and dairy products are from two main types: Lipoprotein lipase, which naturally occurs in raw milk, and bacterial lipases produced predominantly by psychrotrophic bacteria due to contamination. Milk lipase can be inactivated by pasteurization, but bacterial lipases are heat stable, meaning they can survive through processing and cause lipolysis during storage [34]. The hydrolysis of lipids in milk produces free fatty acids, partial glycerides, and possibly glycerol. The free fatty acids cause both undesirable and desirable properties: Short-chain fatty acids, such as butanoic acid and hexanoic acid, are responsible for the off-aromas known as "vinegar", "cheesy", "sweaty", and "soapy" in dairy products [44]. However, in the manufacture of Parmesan and Romano cheese, lipases are used to produce fatty acids that contribute to the characteristic piquant flavor [34]. Besides short-chain fatty acids, methyl ketones are an important volatile group derived from lipolysis $[33,34,45]$. Their generation pathway involves fatty acid oxidation to $\beta$-ketoacids, followed by decarboxylation to corresponding methyl ketones with one carbon atom less $[11,46]$ (Figure 2). Similar to free fatty acids, methyl ketones contribute to the characteristic aroma of blue-veined cheese [47]. However, they can have a negative influence on the flavor profile of milk products, especially Ultra-high temperature milk [48]. Both methyl ketones and acid groups have a wide range of odor detection thresholds, from ppm to ppt levels. Therefore, the contribution of the two groups to dairy aroma profiles, to a great extent, depends on the attributes of an individual compound. For example, 2-heptanone, with an odor threshold of $1.3 \mathrm{ppb}$ in air, is an important aroma to the "cooked" note in UHT milk. Acetic acid, with a "vinegar-like" odor property, was found to be a significant off-aroma in whey protein concentrates and isolates [20]. Compounds, such as 2-pentanone and 2-decanone, are not likely to be significant contributors to off-aromas because of their relatively high detection thresholds. 
Table 2. Odor thresholds and formation mechanisms of off-aroma compounds derived from lipid autoxidation and lipolysis.

\begin{tabular}{|c|c|c|c|c|}
\hline $\begin{array}{l}\text { Chemical } \\
\text { Groups }\end{array}$ & Volatile Compounds & Odor Thresholds & Precursors & Formation Mechanisms \\
\hline \multirow[t]{7}{*}{ Aldehydes } & Heptanal & $250 \mathrm{ppt}$ in air [49] & Oleic acid [50] & Autoxidation [50] \\
\hline & Octanal & 7.8 ppt in air [49] & Oleic acid [50] & Autoxidation $[37,50]$ \\
\hline & Pentanal & 39 ppt in air [51] & Linoleic acid [38] & Autoxidation [38] \\
\hline & $(E, Z)-2,4$-Decadienal & $0.04-0.16 \mathrm{ppt}$ in air [53] & Linoleic acid [38] & Autoxidation [38] \\
\hline & $(E, Z)-2,6-$ Nonadienal & $3.8 \mathrm{ppb}$ in oil $[54,55]$ & Linolenic acid [42] & Autoxidation [42] \\
\hline & Propanal & $690 \mathrm{ppt}$ in air [49] & Linolenic acid [11] & Autoxidation $[37,38]$ \\
\hline & (E)-2-Hexenal & 480 ppt in air [49] & Linolenic acid [38] & Autoxidation [38] \\
\hline \multirow{4}{*}{ Alcohols } & Hexanol & $2.5 \mathrm{ppm}$ in water [42] & Linoleic acid [59] & Autoxidation [59] \\
\hline & Pentanol & 4 ppm [42] & Linoleic acid [38] & Autoxidation [38] \\
\hline & 1-Penten-3-ol & $4.3 \mathrm{ppb}$ in air [49] & Linolenic acid [60] & Autoxidation [60] \\
\hline & 1-Octen-3-ol & 48 ppt in air [49] & Linoleic acid [38] & Autoxidation [38] \\
\hline \multirow[t]{3}{*}{ Ketones } & 1-Octen-3-one & $0.03-1.12 \mathrm{ppt}$ in air [54] & $\begin{array}{l}\text { Linoleic acid or linolenic } \\
\text { acid [13] }\end{array}$ & Autoxidation [61] \\
\hline & 1-Penten-3-one & $1.3 \mathrm{ppb}$ in water [62] & Linolenic acid [60] & Autoxidation [60] \\
\hline & (Z)-1,5-Octadien-3-one & $0.003-0.006 \mathrm{ppt}$ in air [54] & Linolenic acid [42] & NA \\
\hline Methyl ketones & 2-Nonanone & $1.7 \mathrm{ppb}$ in air [49] & Triglycerides [11] & Lipolysis [11] \\
\hline \multirow[t]{4}{*}{ Acids } & Butanoic acid & $240 \mathrm{ppb}$ in water [58] & Triglycerides [11] & Lipolysis [61] \\
\hline & Acetic acid & $60 \mathrm{ppt}$ in air [66] & Triglycerides [11] & Lipolysis [11,46] \\
\hline & Hexanoic acid & 3 ppm in water [67] & Triglycerides $[23,68]$ & Lipolysis $[23,68]$ \\
\hline & 3-Methylbutanoic acid & $1.5 \mathrm{ppt}$ in air [66] & Triglycerides $[23,68]$ & Lipolysis $[23,68]$ \\
\hline \multirow[t]{2}{*}{ Furans } & 2-Pentylfuran & $270 \mathrm{ppt}$ in air [49] & Linoleic acid [37] & Autoxidation [37] \\
\hline & 2-Ethyl furan & 2-27 ppm [65] & 2,4-Decadienal [13] & Autoxidation [13] \\
\hline
\end{tabular}

NA: Not available.

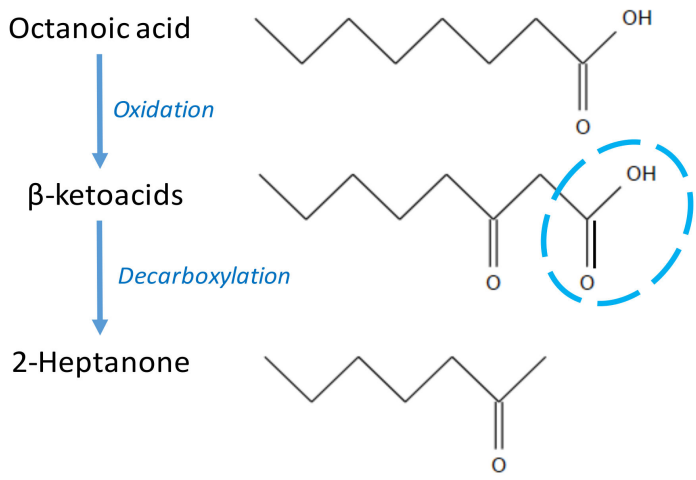

Figure 2. The formation of heptanone through the lipolysis pathway as an example of methyl ketone formation from $\beta$-oxidation and decarboxylation of fatty acids. 


\subsection{Maillard Reaction}

Maillard reaction is a vitally important class of chemical deterioration in dairy products. Nonenzymatic browning generally occurs during heat processing, such as pasteurization, and storage at moderate to high temperatures. The reaction requires a carbonyl group from a reducing sugar and an amino group from a protein, peptide, or amino acid. Specifically, it involves the formation of unstable glycosylamine from the condensation of carbonyl and amino groups, and the Amadori compound is formed from the rearrangement of glycosylamine. The Amadori compound then undergoes various reaction pathways, including fissions, dehydration, and condensation, before generating desirable and undesirable flavors $[10,69,70]$. Lactose is usually the primary reducing sugar in dairy ingredients involved in Maillard reaction [44]. Milk proteins and lactose subjected to Maillard browning generate a wide variety of odorants, namely Strecker aldehydes, sulfur- and nitrogen-containing compounds, maltol, and diacetyl [28,71]. Off-aromas generated from Maillard reaction in dairy products are shown in Table 3. Amino acids and sugars are the exclusive precursors for almost all the undesirable flavors. Amino acids, especially sulfur-containing cysteine and methionine, are primary precursors of compounds responsible for "garlic", "cabbage", "potato", and "popcorn" notes. Sulfur-containing off-aromas are frequently studied due to their extremely low odor thresholds and sensory importance. Methional, methanethiol, and dimethyl sulfide are formed from Maillard reaction by Strecker degradation [72] from methionine. Methanethiol is then oxidized to dimethyl disulfide and dimethyl trisulfide progressively [23]. Interestingly, the odor thresholds of dimethyl sulfide, dimethyl disulfide, and dimethyl trisulfide decrease dramatically as oxidation progresses, suggesting that the off-aroma profile might change greatly during storage. As a result, the oxygen content in the environment might affect the sensory attributes of dairy products significantly, by impacting the oxidation rate of Maillard reaction compounds. Some aldehydes, like 3-methylbutanal, 2-methylbutanal, 2-methylpropanal, and phenylacetaldehyde, are Strecker degradation products of leucine, isoleucine, valine, and phenylalanine, respectively [73,74]. Besides, many heterocyclic compounds, such as 2-acetyl-1-pyrroline, 2-acetyl-2-thiazoline, and 2-propionyl-1-pyrroline, have low odor detection thresholds and are considered to be potent volatile compounds.

Various parameters, including $\mathrm{pH}$, time, temperature, and water activity, are known to influence the overall outcome of Maillard reaction: In general, alkaline conditions, intermediate water activity (0.5-0.8), elevated temperature, and prolonged time increase the rate of Maillard reaction [75]. The nature of the reactants also has a direct influence on the rate of Maillard browning. For instance, lysine and glycine allow for a higher degree of reaction compared to cysteine [75]. It is important to keep in mind that Maillard reaction is not only the cause of off-aromas but is also a rich source of desirable flavors [69]. In conclusion, depending on the sensory expectation of a particular food system, Maillard browning could be tailored to either promote or inhibit reactions in order to achieve a particular sensory goal for products.

Table 3. Off-aromas generated from the Maillard reaction pathway in dairy ingredients.

\begin{tabular}{|c|c|c|c|c|c|}
\hline Dairy Products & Off-Aromas & $\begin{array}{c}\text { Odor } \\
\text { Attributes }\end{array}$ & Odor Threshold & Precursors & $\begin{array}{l}\text { Off-Aroma } \\
\text { References }\end{array}$ \\
\hline \multirow{4}{*}{ Liquid whey } & Dimethyl trisulfide & Garlic & $0.01 \mathrm{ppb}$ in water [76] & Methionine [72] & \multirow{4}{*}{ [24] } \\
\hline & 2-Acetyl-1-pyrroline & Popcorn & $0.1 \mathrm{ppb}$ in water [42] & Proline [77] & \\
\hline & Methional & Potato & $0.1-0.2 \mathrm{ppt}$ in air [78] & Methionine [23] & \\
\hline & 2-Methoxy-3-isopropylpyrazine & Earthy & $\begin{array}{l}0.0005-0.001 \mathrm{ppt} \\
\text { in air [79] }\end{array}$ & $\begin{array}{l}\text { Peptides or free amino } \\
\text { acids [80] }\end{array}$ & \\
\hline \multirow{5}{*}{$\begin{array}{l}\text { Milk protein } \\
\text { concentrate } \\
\text { and isolate }\end{array}$} & Sotolon & Spice & 0.015 ppt in air [66] & $\begin{array}{l}\text { Glutamic acid and } \\
\text { pyruvate [81] }\end{array}$ & \multirow{5}{*}{ [26] } \\
\hline & Benzothiazole & Carpet & $80 \mathrm{ppb}$ in water [42] & $\begin{array}{l}\text { Sulfur-containing } \\
\text { precursors }\end{array}$ & \\
\hline & 2-Aminoacetophenone & Tortilla & $0.2 \mathrm{ppb}$ in water [82] & Tryptophan [82] & \\
\hline & 3-Methylbutanal & Malty & $3-6$ ppt in air [79] & Leucine [73] & \\
\hline & 2-Methylbutanal & Cocao & $1 \mathrm{ppb}$ in water $[83]$ & Isoleucine [84] & \\
\hline
\end{tabular}


Table 3. Cont.

\begin{tabular}{|c|c|c|c|c|c|}
\hline Dairy Products & Off-Aromas & $\begin{array}{c}\text { Odor } \\
\text { Attributes }\end{array}$ & Odor Threshold & Precursors & $\begin{array}{l}\text { Off-Aroma } \\
\text { References }\end{array}$ \\
\hline \multirow{2}{*}{$\begin{array}{l}\text { Nonfat dry } \\
\text { milk }\end{array}$} & 2-Acetyl-2-thiazoline & Popcorn & $\begin{array}{l}0.016-0.022 \mathrm{ppt} \\
\text { in air [79] }\end{array}$ & Cysteine or cystine [77] & \multirow[t]{2}{*}{ [26] } \\
\hline & 2-Acetylthiazole & Popcorn & $10 \mathrm{ppb}$ in water [85] & Cysteine [84] & \\
\hline \multirow{5}{*}{$\begin{array}{l}\text { Whey protein } \\
\text { concentrate }\end{array}$} & Diacetyl & Buttery & 5 ppt in air [49] & Glucose and proline [86] & \multirow{5}{*}{ [21] } \\
\hline & Dimethyl disulfide & Garlic & $0.16 \mathrm{ppb}$ in water [87] & Methionine [72] & \\
\hline & 2-Methyl-3-furanthiol & Vitamins & 0.0025 ppt in air [56] & Multiple origins [88] & \\
\hline & 2-Acetylpyridine & Popcorn & $19 \mathrm{ppb}$ in water [89] & Cysteine [84] & \\
\hline & Phenylacetaldehyde & Floral & $0.6-1.2 \mathrm{ppt}$ in air [78] & Phenylalanine [74] & \\
\hline \multirow{5}{*}{$\begin{array}{l}\text { Sweet whey } \\
\text { powder }\end{array}$} & 2,6-Dimethylpyrazine & Cooked meat & $\begin{array}{c}200-9000 \mathrm{ppb} \\
\text { in water [90] }\end{array}$ & $\begin{array}{l}\text { Peptides or free amino } \\
\text { acids [80] }\end{array}$ & \multirow{5}{*}{ [23] } \\
\hline & 2,5-Dimethylpyrazine & Cooked potato & $\begin{array}{l}0.8-1.8 \mathrm{ppm} \\
\text { in water [90] }\end{array}$ & $\begin{array}{c}\text { Peptides or free amino } \\
\text { acids [80] }\end{array}$ & \\
\hline & 2-Ethylpyrazine & Roasted nuts & $\begin{array}{c}6-22 \text { ppm } \\
\text { in water [90] }\end{array}$ & $\begin{array}{c}\text { Peptides or free amino } \\
\text { acids [80] }\end{array}$ & \\
\hline & 2,3-Dimethylpyrazine & Nutty & $\begin{array}{l}2.5-35 \mathrm{ppm} \\
\text { in water [90] }\end{array}$ & $\begin{array}{c}\text { Peptides or free amino } \\
\text { acids [80] }\end{array}$ & \\
\hline & 2-Propionyl-1-pyrroline & Fried & $0.02 \mathrm{ppt}$ in air [77] & Proline [77] & \\
\hline \multirow{5}{*}{$\begin{array}{l}\text { Whey protein } \\
\text { hydrolysates }\end{array}$} & Dimethyl sulfide & Sulfur & $1.0 \mathrm{ppb}$ in water [85] & Methionine [72] & \multirow{5}{*}{ [22] } \\
\hline & Dimethyl trisulfide & Cabbage & $\begin{array}{c}0.06-1.2 \mathrm{ppt} \\
\text { in air [78] }\end{array}$ & Methionine [72] & \\
\hline & 3-Methylbutanal & Malty & $3-6$ ppt in air [79] & Leucine [73] & \\
\hline & 2-Methylbutanal & Malty/Chocolate & $1 \mathrm{ppb}$ in water $[83]$ & Isoleucine [73] & \\
\hline & Methional & Potato & $0.1-0.2 \mathrm{ppt}$ in air [78] & Methionine [74] & \\
\hline \multirow{4}{*}{ UHT milk } & Hydrogen sulfide & Rotten eggs & $10 \mathrm{ppb}$ in water [85] & Thiamine or cysteine [48] & \multirow{4}{*}[48,91]{} \\
\hline & Methanethiol & Rotten cabbage & $0.2 \mathrm{ppb}$ in water [92] & Methionine [74] & \\
\hline & 2-Methylpropanal & Pungent & 1 ppm in water [93] & Valine [73] & \\
\hline & 2-Furaldehyde & Woody & 3 ppm in water [62] & Sugar $[94,95]$ & \\
\hline
\end{tabular}

\section{Analytical Methods for Measuring Off-Aromas}

\subsection{General Methods}

The detectable odor thresholds for off-note volatile compounds are usually at parts-per-million (ppm), parts-per-billion (ppb), or even parts-per-trillion (ppt) levels. Therefore, identification and determination of off-aromas becomes challenging and requires sensitive instrumentation. Due to the nature of volatiles, the regular toolbox used by flavor chemists is usually sufficient for off-aroma analysis. Based on the differences in the polarity of odorants and various physical properties of matrices, extraction of aroma or off-aroma from a wide range of samples could be achieved with many approaches, including direct solvent extraction, liquid-liquid extraction, solid-phase extraction/microextraction, and stir bar sorptive extraction. Liquid-liquid extraction is a time-consuming approach and may cause decomposition of unstable volatiles. It is occasionally used owing to its relatively low equipment investment. Solid-phase extraction/microextraction and stir bar sorptive extraction are popular techniques because of their simple sample preparation, acceptable reproducibility, and environmentally friendly nature [96]. Stir bar sorptive extraction has higher sensitivity compared to solid-phase microextraction due to the large phase ratio between the sample and stir bar coating [97]. Solvent-assisted flavor evaporation is also a good option because of its exhaustive volatile extraction and minimal thermal artifacts during isolation $[98,99]$. Many studies employed direct solvent extraction plus solvent-assisted flavor evaporation $[20,21,23]$ or solid-phase microextraction $[31,50,100,101]$ for determining off-aromas in dairy ingredients. The identification and quantitation of odorants, as previously discussed, is usually achieved through well-established flavor research instrumentation, such as gas chromatography-mass spectrometry (GC-MS), flame ionization detectors (GC-FIDs), or pulsed flame photometric detectors (GC-PFPDs) equipped with olfactometry. It is worth noting that PFPD has the capability of sensitively and selectively detecting low concentration sulfur-containing compounds [102]. 


\subsection{Novel Approaches}

Several novel flavor analysis methods have been developed and refined over the past few decades in order to resolve the major disadvantages of classic GC methods, such as limited separation and resolution, tedious sample pretreatment, and aroma isolation. As a high-resolution analytical method, multidimensional gas chromatography (MDGC) has evolved into promising technology to enhance the resolving power of aroma analysis by incorporating multiple separation dimensions; namely, more than one GC column [103]. Since a considerable challenge for aroma analysis is overlapping chromatographic peaks resulting from complex matrices, the MDGC technology can improve the separation of samples of interest and enhance identification more reliably. While MDGC is innovative for advanced separation and detection, adoption of this method is primarily restricted to academic settings, the industry application is still limited. Nevertheless, MDGC is a potential approach to improve the understanding of aroma perception, and it could be adapted for rapid determination of off-aromas in the dairy industry. On-line chemical ionization mass spectrometry (on-line CIMS) has become a powerful tool in real-time detection of food-related aromas. The real-time detection advantages of on-line CIMS make it feasible to explore the aroma release dynamics from food. More importantly, this highly sensitive technique enables samples to be analyzed without mandatory yet time-consuming pretreatment practices from routine aroma extraction and enrichment, so the sampling frequency of the technique achieves several hertz $(\mathrm{Hz})$ [104]. However, this technique is not ideal for chemical-structural elucidation when compared to classic and specific GC-MS approaches [104]. Additionally, the food industry has started to incorporate machine olfaction as a regular instrumental operation for quality control, research, and development. The electronic nose has been successfully applied for evaluating fresh flavor in milk [105] and off-aroma in pineapples [106]. In general, machine olfaction devices are less time-consuming, more portable, and cost effective compared to traditional analytical methods and sensory panels. However, the complete replacement of human sensory perception with machine olfaction is not yet possible [107].

Advanced data analysis techniques have been incorporated in understanding and predicting aroma behaviors in foods [108-110]. An accurate predictive model was developed by Viry et al. (2018) [109] for flavor partitioning and protein-flavor interactions in fat-free dairy solutions. Chen, Husny, and Rabe (2018) processed raw instrumental data and examined its correlation to sensory results by use of the machine learning approach, and successfully predicted the fishiness off-flavor in dairy powders [110]. These novel data processing approaches are receiving increasing attention and may soon be widely recognized and adopted for dairy ingredients.

\section{Strategies to Minimize Off-Notes in Dairy Ingredients}

The flavor of dairy ingredients is of significance because off-aromas will be carried into the finished products [20] and become problematic for consumer acceptability. Off-aromas can be introduced at the milk origin, processing, handling, and storage stages. The effect of processing and storage treatments on off-note generation is significant. Heating temperature and time, oxygen exposure, water activity, packaging materials, and lighting conditions will all have direct or indirect influences on the reaction rate of lipid oxidation, Maillard reaction, and sugar degradation. Improving the understanding of sensory descriptors and chemical natures of off-aroma as well as investigating their formation pathways would be the fundamental approach to unveil flavor deterioration. For instance, by knowing an elevated temperature during thermal processing is a preferred condition for Maillard reaction, the manufacturers might be able to mitigate or at least reduce a "potato" off-note in a finished bottle by decreasing the processing temperature. In short, selecting ingredients with caution and optimizing manufacturing conditions with specific targets can be helpful for minimizing undesirable flavor impacts in the final dairy-related products. 


\section{Conclusions}

This review established the connection between off-aroma lexicons and chemical structures existing in dairy ingredients. Furthermore, the possible formation precursors and mechanisms of major undesirable odorants were explored and compiled. With the growth of consumer interest in dairy protein ingredients, a good understanding of off-aromas and their generation pathways is believed to be useful in overcoming the flavor challenges of high protein formulations. Many off-aromas are break-down compounds from proteins, fats, and sugars via lipid degradation and Maillard reaction pathways. In order to minimize off-aromas over time, manufacturers should carefully select the starting dairy ingredients for protein-based products and adjust the processing parameters to decrease the rate of flavor degradation. Controlling storage conditions will also be helpful for minimizing off-note development. Measuring undesirable odorants in dairy ingredients is time-consuming and detail-demanding work despite the recent development of new technologies. The majority of off-aroma investigation is still performed by use of classic flavor analysis tools. The review will facilitate solution development to effectively control off-note formation and improve consumer experiences regarding dairy-related products.

Author Contributions: Conceptualization: M.T., S.R., Y.Y. and X.L.; Literature review: X.S., Y.Y., A.H. and K.W.; Tables and Figures: Y.Y. and X.S., Writing and review: X.S., Y.Y. and X.L.; Editing: everyone; Revisions and Final editing: X.S. and K.W. All authors have read and agreed to the published version of the manuscript.

Funding: The APC was funded by Virginia Tech Open Access Subvention Fund.

Conflicts of Interest: The authors declare no conflict of interest.

\section{References}

1. Cadwallader, K.R. Flavor challenges in functional beverages. In Handbook of Functional Beverages and Human Health; Shahidi, F., Alasalvar, C., Eds.; CRC Press: Boca Raton, FL, USA, 2016; Volume 11, pp. 27-34.

2. Kilcast, D. Sensory evaluation of taints and off-flavors. In Food Taints and Off-Flavors, 2nd ed.; Saxby, M.J., Ed.; Springer Science \& Business Media: Berlin/Heidelberg, Germany, 1996; pp. 1-38.

3. Prescott, J.; Norris, L.; Kunst, M.; Kim, S. Estimating a "consumer rejection threshold" for cork taint in white wine. Food Qual. Prefer. 2005, 16, 345-349. [CrossRef]

4. Margaria, C.A.; Goodner, K.L.; Baldwin, E.A.; Goodrich, R.M. Detection and identification threshold values for key flavor components in an orange juice matrix. Proc. Fla. State Hort. Soc. 2002, 115, 53-54.

5. Reineccius, G. Off-flavors in foods. In Source of Flavors, 2nd ed.; Chapman \& Hall: London, UK, 1994; pp. 116-138.

6. Drake, M.A.; Miracle, R.E.; Wright, J.M. Sensory properties of dairy proteins. In Milk Proteins, 2nd ed.; Singh, H., Boland, M., Thompson, A., Eds.; Academic Press: Cambridge, UK, 2014; pp. 473-492.

7. Bashi, Z.; McCullough, R.; Ong, L.; Ramirez, M. Alternative Proteins: The Race for Market Share is On. Available online: https://www.mckinsey.com/industries/agriculture/our-insights/alternative-proteins-therace-for-market-share-is-on (accessed on 5 January 2020).

8. Adams, C.; Maluf, I.T.; Meilhac, L.; Ramirez, M.; Paula, R.U. A Winning Growth Formula for Dairy. Available online: https://www.mckinsey.com/industries/consumer-packaged-goods/our-insights/a-winning-growthformula-for-dairy (accessed on 5 January 2020).

9. CAGR of Dairy Protein Market is Expected to Grow 5.8\% in the Year (2019-2023), Predicts Market Research Future, Also Includes Market Analysis, Applications, Product Types, Top-Most Manufacturers. Available online: https://www.theexpresswire.com/pressrelease/_10265749 (accessed on 5 January 2020).

10. McGorrin, R.J. Protein + flavor $=$ a formulation challenge. In Proceedings of the 2018 Protein Trends and Technologies Seminar, Itasca, IL, USA, 22-23 May 2018.

11. Cadwallader, K.R.; Singh, T.K. Flavours and off-flavours in milk and dairy products. In Advanced Dairy Chemistry, 3rd ed.; McSweeney, P.L.H., Fox, P.F., Eds.; Springer: Boston, MA, USA, 2009; Volume 3, pp. 631-690. 
12. Bassette, R.; Fung, D.Y.C.; Mantha, V.R.; Marth, E.H. Off-flavors in milk. C R C Crit. Rev. Food Sci. Nutr. 1986, 24, 1-52. [CrossRef]

13. Jelen, H.H. Solid-phase microextraction in the analysis of food taints and off-odors. J. Chromatogr. Sci. 2006, 44, 399-415. [CrossRef] [PubMed]

14. Delahunty, C.M.; Eyres, G.; Dufour, J.-P. Gas chromatography-olfactometry. J. Sep. Sci. 2006, 29, $2107-2125$. [CrossRef] [PubMed]

15. Friedrich, J.E.; Acree, T.E. Gas Chromatography Olfactometry (GC/O) of Dairy Products. Int. Dairy J. 1998, 8, 235-241. [CrossRef]

16. Whetstine, M.C.; Croissant, A.; Drake, M. Characterization of Dried Whey Protein Concentrate and Isolate Flavor. J. Dairy Sci. 2005, 88, 3826-3839. [CrossRef]

17. Kurtz, A.J.; Lawless, H.T.; Acree, T.E. The Cross-Adaptation of Green and Citrus Odorants. Chemosens. Percept. 2010, 3, 149-155. [CrossRef]

18. Zhao, H.; Ivic, L.; Otaki, J.M.; Hashimoto, M.; Mikoshiba, K.; Firestein, S. Functional expression of a mammalian odorant receptor. Science 1998, 279, 237-242. [CrossRef]

19. Belitz, H.D.; Grosch, W.; Schieberle, P. Aroma compounds. In Food Chemistry, 3rd ed.; Hessel, P., Sprinz, C., Jordan, S., Burghagen, M., Eds.; Springer: Berlin/Heidelberg, Germany, 2004; pp. 342-408.

20. Wright, J.M.; Whetstine, M.E.C.; Miracle, R.E.; Drake, M. Characterization of a Cabbage Off-flavor in Whey Protein Isolate. J. Food Sci. 2006, 71, C86-C90. [CrossRef]

21. Evans, J.; Zulewska, J.; Newbold, M.; Drake, M.; Barbano, D. Comparison of composition and sensory properties of $80 \%$ whey protein and milk serum protein concentrates. J. Dairy Sci. 2010, 93, 1824-1843. [CrossRef] [PubMed]

22. Leksrisompong, P.P.; Miracle, R.E.; Drake, M. Characterization of Flavor of Whey Protein Hydrolysates. J. Agric. Food Chem. 2010, 58, 6318-6327. [CrossRef] [PubMed]

23. Mahajan, S.; Goddik, L.; Qian, M. Aroma Compounds in Sweet Whey Powder. J. Dairy Sci. 2004, 87, 4057-4063. [CrossRef]

24. Karagul-Yuceer, Y.; Drake, M.; Cadwallader, K. Aroma-active Components of Liquid Cheddar Whey. J. Food Sci. 2003, 68, 1215-1219. [CrossRef]

25. Smith, T.; Campbell, R.; Jo, Y.; Drake, M. Flavor and stability of milk proteins. J. Dairy Sci. 2016, 99, 4325-4346. [CrossRef]

26. Karagül-Yüceer, Y.; Drake, M.; Cadwallader, K.R. Aroma-Active Components of Nonfat Dry Milk. J. Agric. Food Chem. 2001, 49, 2948-2953. [CrossRef]

27. Whetstine, M.E.C.; Drake, M. The Flavor and Flavor Stability of Skim and Whole Milk Powders. In Flavor of Dairy Products; Cadwallader, K.R., Drake, M.A., McGorrin, R.J., Eds.; ACS Publications: Washington, DC, USA, 2007; pp. 217-251.

28. Jo, Y.; Benoist, D.; Barbano, D.; Drake, M. Flavor and flavor chemistry differences among milks processed by high-temperature, short-time pasteurization or ultra-pasteurization. J. Dairy Sci. 2018, 101, 3812-3828. [CrossRef]

29. Jensen, S.; Jansson, T.; Eggers, N.; Clausen, M.R.; Larsen, L.B.; Jensen, H.B.; Ray, C.; Sundgren, A.; Andersen, H.J.; Bertram, H.C. Storage-induced changes in the sensory characteristics and volatiles of conventional and lactose-hydrolyzed UHT processed milk. Eur. Food Res. Technol. 2015, 240, 1247-1257. [CrossRef]

30. Park, C.W.; Drake, M. Condensed milk storage and evaporation affect the flavor of nonfat dry milk. J. Dairy Sci. 2016, 99, 9586-9597. [CrossRef]

31. Park, C.; Drake, M. The Distribution of Fat in Dried Dairy Particles Determines Flavor Release and Flavor Stability. J. Food Sci. 2014, 79, 452-459. [CrossRef]

32. Tehrany, E.; Sonneveld, K. Packaging and the Shelf Life of Milk Powders. In Food Packaging and Shelf Life, 1st ed.; Robertson, G.L., Ed.; CRC Press: Boca Raton, FL, USA, 2009; pp. 137-151.

33. Deeth, H.C. Lipoprotein lipase and lipolysis in milk. Int. Dairy J. 2006, 16, 555-562. [CrossRef]

34. Deeth, H. Milk Lipids | Lipolysis and Hydrolytic Rancidity. In Encyclopedia of Dairy Sciences; Academic Press: San Diego, CA, USA, 2011; pp. 721-726.

35. Frankel, E. Lipid oxidation. Prog. Lipid Res. 1980, 19, 1-22. [CrossRef] 
36. Shahidi, F.; Zhong, Y. Lipid oxidation and improving the oxidative stability. Chem. Soc. Rev. 2010, 39, 4067-4079. [CrossRef]

37. Ho, C.T.; Chen, Q. Lipids in food flavors: An overview. In Lipids in Food Flavors; Ho, C.T., Hartman, T.G., Eds.; ACS Publications: Washington, DC, USA, 1994; Volume 558, pp. 2-14.

38. Choe, E.; Min, D.B. Mechanisms and Factors for Edible Oil Oxidation. Compr. Rev. Food Sci. Food Saf. 2006, 5, 169-186. [CrossRef]

39. Ho, C.; Zhang, Y.; Shi, H.; Tang, J. Flavor chemistry of Chinese foods. Food Rev. Int. 1989, 5, $253-287$. [CrossRef]

40. Ullrich, F.; Grosch, W. Identification of the most intense volatile flavour compounds formed during autoxidation of linoleic acid. Eur. Food Res. Technol. 1987, 184, 277-282. [CrossRef]

41. Moore, R.; Duncan, S.; Rasor, A.; Eigel, W.; O'Keefe, S. Oxidative stability of an extended shelf-life dairy-based beverage system designed to contribute to heart health. J. Dairy Sci. 2012, 95, 6242-6251. [CrossRef]

42. Erten, E.S.; Cadwallader, K.R. Identification of predominant aroma components of raw, dry roasted and oil roasted almonds. Food Chem. 2017, 217, 244-253. [CrossRef]

43. Kochhar, S.P. Oxidative pathways to the formation of off-flavours. In Food Taints and Off-Flavours; Saxby, M.J., Ed.; Springer: Boston, MA, USA, 1996; pp. 168-225.

44. Campbell, R.; Drake, M. Invited review: The effect of native and nonnative enzymes on the flavor of dried dairy ingredients. J. Dairy Sci. 2013, 96, 4773-4783. [CrossRef]

45. Shahidi, F. Lipids in Flavor Formation. In Flavor Chemistry; Risch, S.J., Ho, C.T., Eds.; ACS Publications: Washington, DC, USA, 2000; Volume 756, pp. 24-43.

46. Contarini, G.; Povolo, M.; Leardi, R.; Toppino, P.M. Influence of Heat Treatment on the Volatile Compounds of Milk. J. Agric. Food Chem. 1997, 45, 3171-3177. [CrossRef]

47. Gripon, J.C.; Monnet, V.; Lamberet, G.; Desmazeaud, M. Microbial enzymes in cheese ripening. Food Enzymol. 1991, 1, 131-168.

48. Al-Attabi, Z.; D'Arcy, B.R.; Deeth, H.C. Volatile sulfur compounds in pasteurised and UHT milk during storage. Dairy Sci. Technol. 2014, 94, 241-253. [CrossRef]

49. Hall, G.; Andersson, J. Volatile fat oxidation products. I. Determination of odour thresholds and odour intensity functions by dynamic olfactometry. Lebensm. Wiss. Technol. 1983, 16, 354-361.

50. Whitson, M.; Miracle, R.; Drake, M. Sensory characterization of chemical components responsible for cardboard flavor in whey protein. J. Sens. Stud. 2010, 25, 616-636. [CrossRef]

51. Boelens, M.; Van Gemert, L. Organoleptic properties of aliphatic aldehydes. Perfum. Flavorist 1987, 12, 31-43.

52. Guth, H.; Grosch, W. Detection of Furanoid Fatty Acids in Soya-Bean Oil-Cause for the Light-Induced Off-Flavour. Fette Seifen Anstrichm. 1991, 93, 249-255. [CrossRef]

53. Gasser, U.; Grosch, W. Primary odorants of chicken broth. Eur. Food Res. Technol. 1990, 190, 3-8. [CrossRef]

54. Pollner, G.; Schieberle, P. Characterization of the Key Odorants in Commercial Cold-Pressed Oils from Unpeeled and Peeled Rapeseeds by the Sensomics Approach. J. Agric. Food Chem. 2016, 64, 627-636. [CrossRef]

55. Guth, H.; Grosch, W. Deterioration of soya-bean oil: Quantification of primary flavour compounds using a stable isotope dilution assay. Lebensm. Wiss. Technol. 1990, 23, 513-522.

56. Buttery, R.G.; Turnbaugh, J.G.; Ling, L.C. Contribution of volatiles to rice aroma. J. Agric. Food Chem. 1988, 36, 1006-1009. [CrossRef]

57. Hofmann, T.; Schieberle, P. Evaluation of the Key Odorants in a Thermally Treated Solution of Ribose and Cysteine by Aroma Extract Dilution Techniques. J. Agric. Food Chem. 1995, 43, 2187-2194. [CrossRef]

58. Josephson, D.B.; Lindsay, R.C. Retro-aldol degradations of unsaturated aldehydes: Role in the formation of c4-heptenal from t2, c6-nonadienal in fish, oyster and other flavors. J. Am. Oil Chem. Soc. 1987, 64, 132-138. [CrossRef]

59. Fazzalari, F. DS48A-EB Compilation of Odor and Taste Threshold Values Data; West ASTM International: Conshohocken, PA, USA, 1978.

60. Zhang, Y.; Guo, S.; Liu, Z.; Chang, S.K. Off-odor related volatiles in soymilk as affected by soybean variety, grinding, and heat-processing methods. J. Agric. Food Chem. 2012, 60, 7457-7462. [CrossRef] [PubMed]

61. Ho, C.-T.; Zheng, X.; Li, S. Tea aroma formation. Food Sci. Hum. Wellness 2015, 4, 9-27. [CrossRef] 
62. White, S.; Fox, K.; Jervis, S.; Drake, M. Influence of heating and acidification on the flavor of whey protein isolate. J. Dairy Sci. 2013, 96, 1366-1379. [CrossRef]

63. Blank, I.; Lin, J.; Fay, L. Aroma impact compounds formed by autoxidation of arachidonic acid. In Frontiers of Flavour Science; Schieberle, P., Engel, K.H., Eds.; Deutsche Forschungsanstalt für Lebensmittelchemie: Freising, Germany, 1999; pp. 3-9.

64. Bingham, E.; Cohrssen, B.; Powell, C.H. Patty's Toxicology, 5th edition in 9 volumes. Chem. Heal. Saf. 2001, 8 , 45-46. [CrossRef]

65. Drumm, T.D.; Spanier, A.M. Changes in the content of lipid autoxidation and sulfur-containing compounds in cooked beef during storage. J. Agric. Food Chem. 1991, 39, 336-343. [CrossRef]

66. Blank, I.; Schieberle, P.; Grosch, W. Quantification of the flavour compounds 3-hydroxy-4, 5-dimethyl-2(5H)-furanone and 5-ethyl-3-hydroxy-4-methyl-2 (5H)-furanone by a stable isotope dilution assay; Allured Publishers: Wheaton, IL, USA, 1993; pp. 103-109.

67. Buttery, R. Quantitative and sensory aspects of flavor of tomato and other vegetables and fruits. In Flavor Science: Sensible Principles and Techniques; Acree, T.E., Teranishi, R., Eds.; American Chemical Society (ACS): Washington, DC, USA, 1993; pp. 259-286.

68. Ferretti, A.; Flanagan, V.P. Nonenzymatic Browning in Edible Spray-Dried Whey. Identification of Some Volatile Components. J. Dairy Sci. 1971, 54, 1769-1771. [CrossRef]

69. Arnoldi, A. The Maillard reaction as a source of off-flavours. In Taints and Off-Flavours in Foods; Elsevier: Amsterdam, The Netherlands, 2003; pp. 162-175.

70. Newton, A.E.; Fairbanks, A.J.; Golding, M.; Andrewes, P.; Gerrard, J.A. The role of the Maillard reaction in the formation of flavour compounds in dairy products-Not only a deleterious reaction but also a rich source of flavour compounds. Food Funct. 2012, 3, 1231. [CrossRef]

71. Singh, T.K.; Cadwallader, K.R.; Drake, M.A. Section XIV. Milk and Milk Products: Biochemical Processes in the Production of Flavor in Milk and Milk Products. In Handbook of Food Products Manufacturing; Hui, Y.H., Ed.; John Wiley and Sons: New York, NY, USA, 2007; pp. 715-748.

72. Demarigny, Y.; Berger, C.; Desmasures, N.; Gueguen, M.; Spinnler, H.E. Flavour sulphides are produced from methionine by two different pathways by Geotrichum candidum. J. Dairy Res. 2000, 67, 371-380. [CrossRef]

73. Whitfield, F.B.; Mottram, D.S. Volatiles from interactions of Maillard reactions and lipids. Crit. Rev. Food Sci. Nutr. 1992, 31, 1-58. [CrossRef] [PubMed]

74. Pripis-Nicolau, L.; De Revel, G.; Bertrand, A.; Maujean, A. Formation of flavor components by the reaction of amino acid and carbonyl compounds in mild conditions. J. Agric. Food Chem. 2000, 48, 3761-3766. [CrossRef]

75. Perez-Locas, C.; Yaylayan, V. The Maillard reaction and food quality deterioration. In Chemical Deterioration and Physical Instability of Food and Beverages; Woodhead Publishing: Cambridge, UK, 2010; pp. 70-94.

76. Buttery, R.G.; Guadagni, D.G.; Ling, L.C.; Seifert, R.M.; Lipton, W. Additional volatile components of cabbage, broccoli, and cauliflower. J. Agric. Food Chem. 1976, 24, 829-832. [CrossRef]

77. Adams, A.; De Kimpe, N. Chemistry of 2-Acetyl-1-pyrroline, 6-Acetyl-1,2,3,4-tetrahydropyridine, 2-Acetyl-2-thiazoline, and 5-Acetyl-2,3-dihydro-4H-thiazine: Extraordinary Maillard Flavor Compounds. Chem. Rev. 2006, 106, 2299-2319. [CrossRef] [PubMed]

78. Blank, I.; Fischer, K.-H.; Grosch, W. Intensive neutral odourants of linden honey Differences from honeys of other botanical origin. Eur. Food Res. Technol. 1989, 189, 426-433. [CrossRef]

79. Rychlik, M.; Schieberle, P.; Grosch, W. Compilation of Odor Thresholds, Odor Qualities and Retention Indices of Key Food Odorants; Deutsche. Forschungsanstalt für Lebensmittelchemie and Institut für Lebensmittelchemie der Technischen Universität München: Garching, Germany, 1998; pp. 1-63.

80. Van Lancker, F.; Adams, A.; De Kimpe, N. Formation of Pyrazines in Maillard Model Systems of Lysine-Containing Dipeptides. J. Agric. Food Chem. 2010, 58, 2470-2478. [CrossRef]

81. Kobayashi, A. Sotolon: Identification, Formation, and Effect on Flavor; ACS Publications: Washington, DC, USA, 1989.

82. Buttery, R.G.; Ling, L.C. Importance of 2-aminoacetophenone to the flavor of masa corn flour products. J. Agric. Food Chem. 1994, 42, 1-2. [CrossRef]

83. Moore, J.E.A.; Forrester, L.J.; Pelosi, P. SPECIFIC ANOSMIA TO ISOBUTYRALDEHYDE: THE MALTY PRIMARY ODOR. Chem. Senses 1976, 2, 17-25. [CrossRef] 
84. Tressl, R. Formation of Flavor Components in Roasted Coffee; American Chemical Society (ACS): Washington, DC, USA, 1989; Volume 409, pp. 285-301.

85. Belitz, H.D.; Grosch, W. Aromastoffe. In Lehrbuch der Lebensmittelchemie; Springer: Berlin/Heidelberg, Germany, 1992; pp. 304-361.

86. Roberts, D.D.; Acree, T.E. Gas Chromatography-Olfactometry of Glucose-Proline Maillard Reaction Products. In Thermally Generated Flavors; Parliment, T.H., Morello, M.J., McGorrin, R.J., Eds.; ACS Publications: Washington, DC, USA, 1994; Volume 543, pp. 71-79.

87. Mulders, E.J. The odour of white bread. Eur. Food Res. Technol. 1973, 151, 310-317. [CrossRef]

88. Hofmann, T.; Schieberle, P. Quantitative Model Studies on the Effectiveness of Different Precursor Systems in the Formation of the Intense Food Odorants 2-Furfurylthiol and 2-Methyl-3-furanthiol. J. Agric. Food Chem. 1998, 46, 235-241. [CrossRef]

89. Buttery, R.G.; Ling, L.C. Additional Studies on Flavor Components of Corn Tortilla Chips. J. Agric. Food Chem. 1998, 46, 2764-2769. [CrossRef]

90. Fors, S.W.; Owen, S.; Hall, W.D.; McLaughlin, J.; Levinson, R. Evaluation of a Diffusion Strategy for School-Based Hypertension Education. Health Educ. Q. 1989, 16, 255-261. [CrossRef] [PubMed]

91. Vazquez-Landaverde, P.A.; Velazquez, G.; Torres, J.; Qian, M. Quantitative determination of thermally derived off-odor compounds in milk using solid-phase microextraction and gas chromatography. J. Dairy Sci. 2005, 88, 3764-3772. [CrossRef]

92. Guth, H.; Grosch, W. Identification of the Character Impact Odorants of Stewed Beef Juice by Instrumental Analyses and Sensory Studies. J. Agric. Food Chem. 1994, 42, 2862-2866. [CrossRef]

93. Guth, H. Quantitation and Sensory Studies of Character Impact Odorants of Different White Wine Varieties. J. Agric. Food Chem. 1997, 45, 3027-3032. [CrossRef]

94. Ledl, F.; Schleicher, E. New Aspects of the Maillard Reaction in Foods and in the Human Body. Angew. Chem. Int. Ed. 1990, 29, 565-594. [CrossRef]

95. Cerny, C. Origin of carbons in sulfur-containing aroma compounds from the Maillard reaction of xylose, cysteine and thiamine. LWT 2007, 40, 1309-1315. [CrossRef]

96. Zhang, Z.; Li, G. A review of advances and new developments in the analysis of biological volatile organic compounds. Microchem. J. 2010, 95, 127-139. [CrossRef]

97. High, R.; Bremer, P.; Kebede, B.; Eyres, G.T. Comparison of Four Extraction Techniques for the Evaluation of Volatile Compounds in Spray-Dried New Zealand Sheep Milk. Molecules 2019, 24, 1917. [CrossRef]

98. Engel, W.; Bähr, W.; Schieberle, P. Solvent assisted flavour evaporation-A new and versatile technique for the careful and direct isolation of aroma compounds from complex food matrices. Eur. Food Res. Technol. 1999, 209, 237-241. [CrossRef]

99. Lozano, P.R.; Drake, M.; Benítez, D.; Cadwallader, K.R. Instrumental and Sensory Characterization of Heat-Induced Odorants in Aseptically Packaged Soy Milk. J. Agric. Food Chem. 2007, 55, 3018-3026. [CrossRef] [PubMed]

100. Croissant, A.; Kang, E.; Campbell, R.; Bastian, E.; Drake, M. The effect of bleaching agent on the flavor of liquid whey and whey protein concentrate. J. Dairy Sci. 2009, 92, 5917-5927. [CrossRef] [PubMed]

101. Qiu, Y.; Smith, T.; Foegeding, E.; Drake, M. The effect of microfiltration on color, flavor, and functionality of 80\% whey protein concentrate. J. Dairy Sci. 2015, 98, 5862-5873. [CrossRef] [PubMed]

102. Davis, P.M.; Qian, M.C. Effect of Wine Matrix Composition on the Quantification of Volatile Sulfur Compounds by Headspace Solid-Phase Microextraction-Gas Chromatography-Pulsed Flame Photometric Detection. Molecules 2019, 24, 3320. [CrossRef]

103. Chin, S.T.; Eyres, G.T.; Marriott, P.J. Gas Chromatography-Mass Spectrometry in Odorant Analysis. In Springer Handbook of Odor; Buettner, A., Ed.; Springer: Boston, MA, USA, 2017; pp. 47-48.

104. Beauchamp, J.; Zardin, E. Odorant Detection by On-line Chemical Ionization Mass Spectrometry. In Springer Handbook of Odor; Buettner, A., Ed.; Springer: Boston, MA, USA, 2017; pp. 49-50.

105. Wang, A.; Dadmun, C.H.; Hand, R.M.; O’Keefe, S.F.; Phillips, J.B.; Anders, K.A.; Duncan, S.E. Efficacy of light-protective additive packaging in protecting milk freshness in a retail dairy case with LED lighting at different light intensities. Food Res. Int. 2018, 114, 1-9. [CrossRef] 
106. Charoenrein, S.; Kaewtathip, T. Analyzing the Effect of Freeze-Thaw Cycle on the Off-Aroma of Pineapple by Using an Electronic Nose Technique. In Water Properties in Food, Health, Pharmaceutical and Biological Systems: ISOPOW 10; Wiley: New York, NY, USA, 2010; pp. 657-661.

107. Guthrie, B. Machine Olfaction. In Springer Handbook of Odor; Buettner, A., Ed.; Springer: Boston, MA, USA, 2017; pp. 55-56.

108. Boelrijk, A.E.; Jong, C.D. Relating analytical and sensory data to predict flavor quality in dairy products. ACS Symp. Ser. 2003, 836, 95-107.

109. Viry, O.; Boom, R.; Avison, S.; Pascu, M.; Bodnár, I. A predictive model for flavor partitioning and protein-flavor interactions in fat-free dairy protein solutions. Food Res. Int. 2018, 109, 52-58. [CrossRef]

110. Chen, C.; Husny, J.; Rabe, S. Predicting fishiness off-flavour and identifying compounds of lipid oxidation in dairy powders by SPME-GC/MS and machine learning. Int. Dairy J. 2018, 77, 19-28. [CrossRef]

(C) 2020 by the authors. Licensee MDPI, Basel, Switzerland. This article is an open access article distributed under the terms and conditions of the Creative Commons Attribution (CC BY) license (http://creativecommons.org/licenses/by/4.0/). 